\title{
Synthesis, structure and electrochemistry of acetylide-bridged mixed metal cluster $\left[\mathrm{Fe}_{2}(\mathrm{CO})_{6}\left(\mu_{3}-\mathrm{S}\right)_{2} \mathrm{~W}\left\{\left(\eta^{5}-\mathrm{C}_{5} \mathrm{H}_{5}\right) \mathrm{W}(\mathrm{CO})_{3}(\mathrm{CCPh})\right\}_{2}\right]$
}

\author{
Pradeep Mathur a,*, Sarbani Mukhopadhyay a , Moawia O. Ahmed a, \\ Goutam K. Lahiri a,*, Soma Chakraborty a, Vedavati G. Puranik ${ }^{\mathrm{b}}$, \\ Mohan M. Bhadbhade ${ }^{\mathrm{b}}$, Shubhangi B. Umbarkar ${ }^{\mathrm{b}}$ \\ ${ }^{a}$ Chemistry Department, Indian Institute of Technology, Bombay, Powai, Bombay 400 076, India \\ ${ }^{\mathrm{b}}$ National Chemical Laboratory, Pune 411 008, India
}

\begin{abstract}
Thermolysis of a toluene solution containing $\left[\mathrm{Fe}_{2} \mathrm{~W}(\mathrm{CO})_{10}\left(\mu_{3}-\mathrm{S}\right)_{2}\right](\mathbf{1})$ and $\left[\left(\eta^{5}-\mathrm{C}_{5} \mathrm{H}_{5}\right) \mathrm{W}(\mathrm{CO})_{3}(\mathrm{CCPh})\right](2)$, at $80^{\circ} \mathrm{C}$ yields the mixed metal cluster $\left[\mathrm{Fe}_{2}(\mathrm{CO})_{6}\left(\mu_{3}-\mathrm{S}\right)_{2} \mathrm{~W}\left\{\left(\eta^{5}-\mathrm{C}_{5} \mathrm{H}_{5}\right) \mathrm{W}(\mathrm{CO})_{3}(\mathrm{CCPh})\right\}_{2}\right]$ (3). Structure of 3 has been established crystallographically. It consists of a triangular $\mathrm{Fe}_{2} \mathrm{~W}$ unit, each face of which is capped by a sulfido ligand. Each $\mathrm{Fe}$ atom bears three carbonyl groups. Two separate molecules of $\left[\left(\eta^{5}-\mathrm{C}_{5} \mathrm{H}_{5}\right) \mathrm{W}(\mathrm{CO})_{3}(\mathrm{CCPh})\right]$ are attached to the $\mathrm{W}$ atom of the $\mathrm{Fe}_{2} \mathrm{~W}$ core through the acetylide groups.
\end{abstract}

Keywords: Clusters; Mixed-metal; Carbonyl; Chalcogen; Acetylide; Electrochemistry

\section{Introduction}

There is continuing interest in metal acetylide chemistry from several perspectives. Metal acetylide complexes can serve as useful precursors for preparation of organometallic polymers [1-6], as components in nonlinear optical materials $[7,8]$, and as new liquid crystals $[9,10]$. Carbon-carbon bond formation reactions by using metal acetylide precursors has been of particular interest [11-15]. Mononuclear acetylide complexes have been shown to undergo different types of coupling reactions on metal clusters, and as a consequence, numerous new acetylide-bridged mixed-metal clusters have been synthesised during the course of these investigations. In previous studies, we have investigated the use of chalcogen-bridged metal carbonyl compounds as precursors to add metal acetylide molecules and have observed several types of acetylide couplings to occur on the chalcogen-bridged metal cluster frameworks. Nature of the chalcogen bridges, the metal acetylide used, and the reaction conditions used in these reac- tions all appear to play important roles in influencing the course of such acetylide couplings. We have observed coupling with and without $\mathrm{CO}$ as well as oxocontaining metal acetylide complexes when the reactions have been performed under aerobic conditions [16-18]. In this paper we report the formation of an unusual acetylide-containing mixed-metal cluster from a mild thermolysis reaction, its structural characterisation and investigation of its electrochemistry (Scheme 1).

\section{Results and discussion}

2.1. Synthesis and characterisation of $\left[\left(\eta^{5}-C_{5} H_{5}\right)_{2}\right.$ $\left.\mathrm{W}_{3} \mathrm{Fe}_{2} \mathrm{~S}_{2}(\mathrm{CO})_{12}(\mathrm{CCPh})_{2}\right]$

When a toluene solution of $\left[\mathrm{Fe}_{2} \mathrm{~W}(\mathrm{CO})_{10}\left(\mu_{3}-\mathrm{S}\right)_{2}\right](\mathbf{1})$ and $\left[\left(\eta^{5}-\mathrm{C}_{5} \mathrm{H}_{5}\right) \mathrm{W}(\mathrm{CO})_{3}(\mathrm{CCPh})\right](2)$ was heated at $80^{\circ} \mathrm{C}$, under nitrogen atmosphere, an immediate color change was observed and after twenty minutes, a dark brown compound was separated in pure form from the reaction mixture, and characterised as $\left[\left(\eta^{5}-\mathrm{C}_{5} \mathrm{H}_{5}\right)_{2} \mathrm{~W}_{3} \mathrm{Fe}_{2} \mathrm{~S}_{2}-\right.$ 


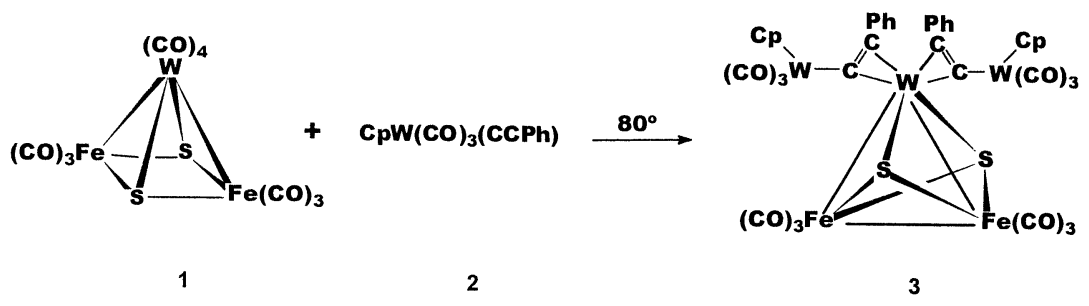

Scheme 1.

Table 1

Crystal data and structure refinement parameters for $\mathbf{3}$

\begin{tabular}{|c|c|}
\hline Empirical formula & $\mathrm{C}_{19} \mathrm{H}_{10} \mathrm{FeO}_{6} \mathrm{SW}_{1.50}$ \\
\hline Formula weight & 697.96 \\
\hline Temperature (K) & 293(2) \\
\hline Wavelength (̊̊) & 0.70930 \\
\hline Crystal system & Orthorhombic \\
\hline Space group & Pnab \\
\hline \multicolumn{2}{|l|}{ Unit cell dimensions } \\
\hline$a(\AA)$ & $18.921(3)$ \\
\hline$b(\AA)$ & $11.338(1)$ \\
\hline$c(\AA)$ & $18.939(3)$ \\
\hline$V\left(\AA^{3}\right)$ & $4062.9(10)$ \\
\hline$Z$ & 8 \\
\hline$D_{\text {calc }}\left(\mathrm{mg} \mathrm{m}^{-3}\right)$ & 2.282 \\
\hline Absorption coefficient $\left(\mathrm{mm}^{-1}\right)$ & 9.322 \\
\hline$F(000)$ & 2600 \\
\hline Crystal size $\left(\mathrm{mm}^{3}\right)$ & $0.35 \times 0.35 \times 0.3$ \\
\hline Reflections collected/unique & $4249 / 3577$ \\
\hline$\theta$ Range for data collection $\left({ }^{\circ}\right)$ & $2.09-24.92$ \\
\hline Index ranges & $0 \leq h \leq 22,0 \leq k \leq 13,0 \leq l \leq 22$ \\
\hline Completeness to $\theta=24.92(\%)$ & 96.9 \\
\hline Refinement method & $\begin{array}{l}\text { Full-matrix-block least-squares } \\
\text { on } F^{2}\end{array}$ \\
\hline Data/restraints/parameters & $3577 / 0 / 237$ \\
\hline Goodness-of-fit on $F^{2}$ & 0.526 \\
\hline Final $R$ indices $[I>2 \sigma(I)]$ & $R_{1}=0.0488, w R_{2}=0.1286$ \\
\hline$R$ indices (all data) & $R_{1}=0.0635, w R_{2}=0.1406$ \\
\hline $\begin{array}{l}\text { Largest difference peak and } \\
\text { hole }\left(\mathrm{e} \AA^{-3}\right)\end{array}$ & 2.256 and -1.629 \\
\hline
\end{tabular}

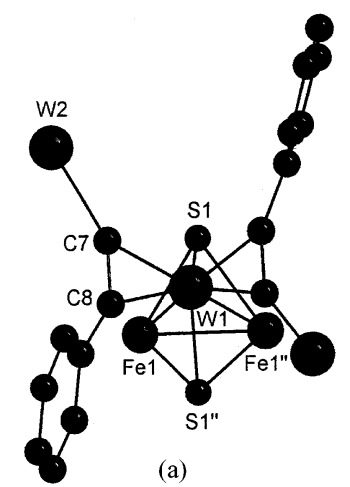

(a)

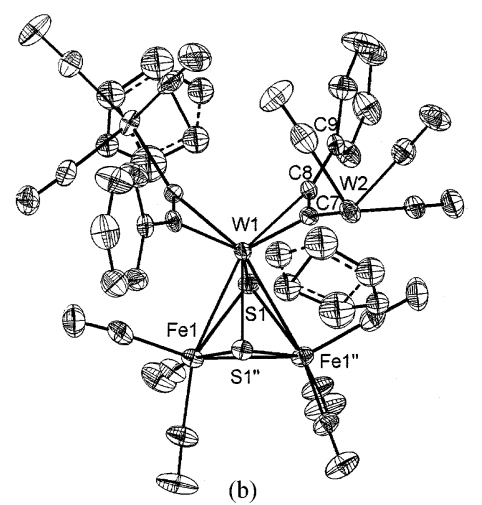

Fig. 1. (a) Ball and stick representation of the core of 3. (b) ORTEP diagram of 3 (with $30 \%$ probability ellipsoids). Two orientations of the disordered $\mathrm{Cp}$ ring are represented by bold and dashed lines, respectively.
Table 2

Selected bond lengths $(\AA)$ and bond angles $\left({ }^{\circ}\right)$ of compound 3

\begin{tabular}{lclc}
\hline $\begin{array}{l}\text { Bond lengths } \\
\mathrm{W}(1)-\mathrm{C}(8)\end{array}$ & $2.051(11)$ & $\mathrm{Fe}(1)-\mathrm{S}(1)$ & $2.308(3)$ \\
$\mathrm{W}(1)-\mathrm{C}(7)$ & $2.084(11)$ & $\mathrm{Fe}(1)-\mathrm{Fe}\left(1^{\prime \prime}\right)$ & $2.535(4)$ \\
$\mathrm{W}(1)-\mathrm{Fe}(1)$ & $2.982(2)$ & $\mathrm{S}(1)-\mathrm{Fe}\left(1^{\prime \prime}\right)$ & $2.319(4)$ \\
$\mathrm{W}(2)-\mathrm{C}(7)$ & $2.194(11)$ & $\mathrm{C}(7)-\mathrm{C}(8)$ & $1.338(16)$ \\
Bond angles & & & \\
$\mathrm{S}(1)-\mathrm{Fe}(1)-\mathrm{W}(1)$ & $50.48(8)$ & $\mathrm{C}(8)-\mathrm{W}(1)-\mathrm{C}\left(8^{\prime \prime}\right)$ & $110.2(6)$ \\
$\mathrm{C}(8)-\mathrm{W}(1)-\mathrm{C}(7)$ & $37.7(5)$ & $\mathrm{Fe}\left(1^{\prime \prime}\right)-\mathrm{Fe}(1)-\mathrm{W}(1)$ & $64.85(4)$ \\
$\mathrm{C}(8)-\mathrm{C}(7)-\mathrm{W}(2)$ & $142.5(9)$ & $\mathrm{C}\left(8^{\prime \prime}\right)-\mathrm{W}(1)-\mathrm{C}(7)$ & $97.8(4)$ \\
$\mathrm{C}(8)-\mathrm{C}(7)-\mathrm{W}(1)$ & $69.8(7)$ & $\mathrm{C}(8)-\mathrm{W}(1)-\mathrm{C}\left(7^{\prime \prime}\right)$ & $97.8(4)$ \\
$\mathrm{W}(2)-\mathrm{C}(7)-\mathrm{W}(1)$ & $147.3(6)$ & $\mathrm{C}\left(8^{\prime \prime}\right)-\mathrm{W}(1)-\mathrm{C}\left(7^{\prime \prime}\right)$ & $37.7(5)$ \\
$\mathrm{C}(9)-\mathrm{C}(8)-\mathrm{C}(7)$ & $145.1(12)$ & $\mathrm{C}(7)-\mathrm{W}(1)-\mathrm{C}\left(7^{\prime \prime}\right)$ & $110.0(6)$ \\
$\mathrm{C}(9)-\mathrm{C}(8)-\mathrm{W}(1)$ & $142.3(9)$ & $\mathrm{S}\left(1^{\prime \prime}\right)-\mathrm{Fe}(1)-\mathrm{W}(1)$ & $50.48(8)$ \\
$\mathrm{C}(7)-\mathrm{C}(8)-\mathrm{W}(1)$ & $72.5(7)$ & & \\
\hline
\end{tabular}

Symmetry transformations used to generate equivalent atoms: $\left(\right.$ atom $\left.^{\prime \prime}\right)=-x+3 / 2, y,-z$.

$(\mathrm{CO})_{12}(\mathrm{CCPh})_{2}$ ] (3). The Se- and Te-anaologs of $1 \mathrm{did}$ not show any reactivity towards 2 under the same reaction conditions. Structural features of $\mathbf{3}$ were identified on the basis of IR and ${ }^{1} \mathrm{H}-\mathrm{NMR}$ spectroscopy. The IR spectrum of $\mathbf{3}$ shows bands due to terminally bonded carbonyl groups and its ${ }^{1} \mathrm{H}-\mathrm{NMR}$ spectrum confirmed the presence of phenyl group and one type of $\left(\eta^{5}-\mathrm{C}_{5} \mathrm{H}_{5}\right)$ group. For an unambiguous determination of the structure of $\mathbf{3}$, single crystals were grown and $\mathrm{X}$-ray structure analysis carried out (Table 1). Dark brown crystals of $\mathbf{3}$ were grown from hexanedichloromethane solvent mixtures at $0^{\circ} \mathrm{C}$. Its molecular structure, shown in Fig. 1, can be described as consisting of an $\mathrm{Fe}_{2} \mathrm{WS}_{2}$ trigonal bipyramidal unit with the $\mathrm{S}$ atoms occupying the apical positions. Each Fe atom bears three terminal carbonyl groups. The $\mathrm{Fe}-\mathrm{W}$ bond distance 2.982(2) $\AA$ is comparable in length with the $\mathrm{Fe}-\mathrm{W}$ bond reported earlier $[19,20]$. The $\mathrm{W}$ atom of the $\mathrm{Fe}_{2} \mathrm{WS}_{2}$ core is attached to two separate molecules of $\left[\left(\eta^{5}-\mathrm{C}_{5} \mathrm{H}_{5}\right) \mathrm{W}(\mathrm{CO})_{3}(\mathrm{CCPh})\right]$ through the acetylide group. The distance between the two acetylide carbon atoms $\mathrm{C}(7)-\mathrm{C}(8)$ is $1.338(16) \AA$ Table 2 . This is comparable to the distance observed for a similar bonding type in $\mathrm{W}(\mathrm{PhC} \equiv \mathrm{CPh})\left(\eta^{8}-\mathrm{C}_{8} \mathrm{H}_{8}\right)(1.31(3) \AA)$ [21]. Formation of $\mathbf{3}$ involves a formal transformation of the $\mathrm{Fe}_{2} \mathrm{WS}_{2}$ square pyramidal core in $\mathbf{1}$ to a trigonal 
bipyramidal geometry by formation of a $\mathrm{Fe}-\mathrm{Fe}$ bond. The $\mathrm{W}$ atom is stripped of its carbonyl group and two molecules of $\mathbf{2}$ bind to it through the acetylide groups. There is no decarbonylation at the metal centers of the adding 2 units and no new bonds are formed between the metal atoms of $\mathbf{2}$ and any of the $\mathrm{Fe}_{2} \mathrm{WS}_{2}$ core atoms of $\mathbf{1}$. The acetylide groups remain uncoupled. This is in marked contrast to the related reactions in which the adding acetylide units undergo decarbonylation and coupling between the acetylide groups with or without $\mathrm{CO}$ is observed [16]. Attempts to induce coupling between the acetylide groups of $\mathbf{3}$ by photolysis or thermolysis resulted in decomposition. Role of the bridging chalcogen atoms in influencing the course of the reactions is apparent. Reactions which favor acetylide coupling may be thought to occur by an initial loss of $\mathrm{CO}$ groups from the $\left[\left(\eta^{5}-\mathrm{C}_{5} \mathrm{R}_{5}\right) \mathrm{M}(\mathrm{CO})_{3}(\mathrm{CCPh})\right](\mathrm{R}=\mathrm{H}$, $\left.\mathrm{CH}_{3} ; \mathrm{M}=\mathrm{Mo}, \mathrm{W}\right)$ and attachment of the coordinatively unsaturated units formed with the lone pairs of the chalcogen atoms of $\left[\mathrm{Fe}_{3}(\mathrm{CO})_{9}\left(\mu_{3}-\mathrm{E}\right)_{2}\right]$. Orientation of the adding metal acetylide units is such that the tail-to-tail or head-to-tail coupling occurs. In these cases several new metal-metal bonds are also formed. An alternate mechanism, as is observed in formation of 3 , is one whereby decarbonylation occurs at a metal center of the chalcogen bridged cluster making this unit an electophile. Decarbonylation in $\mathbf{1}$ occurs at the $\mathrm{W}$ atom rather than the $\mathrm{Fe}$ atoms and thus it is at the $\mathrm{W}$ atom that the addition of two molecules of $\mathbf{2}$ occurs to form 3. Under the milder reaction conditions used in preparation of $\mathbf{3}, \mathbf{2}$ remains intact. Compounds $\left[\mathrm{Fe}_{2} \mathrm{~W}(\mathrm{CO})_{10}\left(\mu_{3}-\mathrm{Se}\right)_{2}\right]$ and $\left[\mathrm{Fe}_{2} \mathrm{~W}(\mathrm{CO})_{10}\left(\mu_{3}-\mathrm{Te}\right)_{2}\right]$ do not undergo decarbonylation under similar conditions and hence do not add $\mathbf{2}$ to form the Se- and Te- analogs of 3.

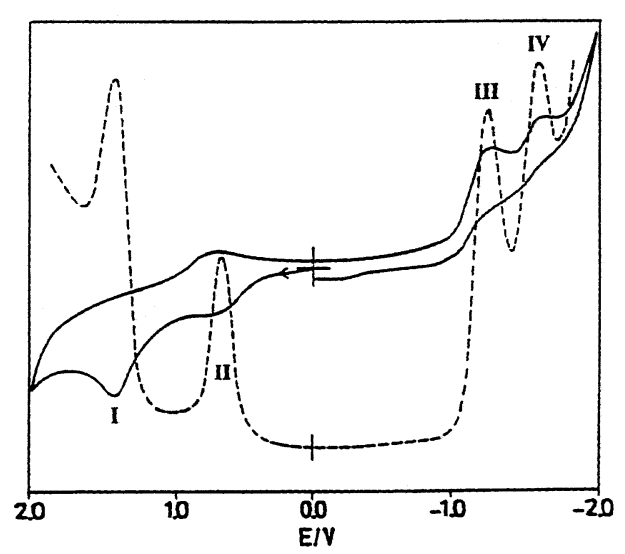

Fig. 2. Cyclic voltammogram (-) and differential pulse voltammograms (---) of 3 in dicholoromethane solvent (scan rate, $50 \mathrm{mV}$ $\left.\mathrm{s}^{-1}\right)$.

\subsection{Redox properties of complex $\mathbf{3}$}

The redox properties of complex $\mathbf{3}$ have been studied by cyclic voltammetric and differential pulse voltammetric techniques in dichloromethane solvent using a platinum working electrode. It exhibits two irreversible oxidative waves, I and II at $E_{\mathrm{pa}}, 0.68$ and $1.43 \mathrm{~V}$ versus SCE, respectively, and two reductive waves III and IV at $E_{\mathrm{pc}},-1.27$ and $-1.59 \mathrm{~V}$ versus $\mathrm{SCE}$, respectively (Fig. 2) (under identical experimental conditions ferrocene/ferrocenium couple appears at $0.58 \mathrm{~V}$ vs. SCE) [22]. The one-electron and two-electron nature of the responses II/IV and I/III, respectively, are established from the cyclic voltammetric as well as differential pulse voltammetric current height considerations [23]. The observed redox processes may be assigned to be associated with the tungsten centers. In $\mathbf{3}$ there are two types of $\mathrm{W}$ centers, $\mathrm{W}_{1} / \mathrm{W}_{2}$ and $\mathrm{W}_{3}$. Since the chemically equivalent $\mathrm{W}_{1}$ and $\mathrm{W}_{2}$ are different from the third one, $\mathrm{W}_{3}$, therefore it can logically be ascribed that the responses I and III are due to the simultaneous oxidation and reduction of the $\mathrm{W}_{1}$ and $\mathrm{W}_{2}$ centers and responses II and IV correspond to the oxidation and reduction of the third $\mathrm{W}_{3}$ center [24].

The electronic spectrum of this complex has been recorded in dichloromethane solvent in the range of $700-190 \mathrm{~nm}$. The complex exhibits multiple transitions in the UV-vis region (Section 3). On the basis of their high intensities the bands are assigned to be charge transfer in nature.

\section{Experimental}

\subsection{General procedures}

Reactions and manipulations were carried out using standard Schlenk line techniques under an atmosphere of pre-purified nitrogen, unless otherwise stated. Solvents were purified, dried, and distilled under an argon or nitrogen atmosphere prior to use. Infrared spectra were recorded on a Nicolet Impact 400 FTIR spectrophotometer, as hexane solutions in $0.1 \mathrm{~mm}$ path length cells; ${ }^{1} \mathrm{H}-\mathrm{NMR}$ spectra were recorded on a Varian VXR-300S spectrometer in $\mathrm{CDCl}_{3}$. Elemental analysis were performed using a Carlo-Erba automatic analyser. Electrochemical measurements were carried out using a PAR model 273 A potentiostat/galvanostat. A platinum wire working electrode (length, $0.3 \mathrm{~cm}$ and diameter, $0.5 \mathrm{~mm}$ ), a platinum wire auxiliary electrode and a saturated calomel electrode (SCE) were used in a three electrode configuration. Tetraethyl ammonium perchlorate (TEAP) was the supporting electrolyte and the solute concentration was $\sim 10^{-3} \mathrm{M} . E_{\mathrm{pa}}$ and $E_{\mathrm{pc}}$ are the anodic and cathodic cyclic voltammetric peak potentials respectively. Electronic spectra were recorded 
using a Shimadzu UV-2100 spectrophotometer. The compounds $\left[\mathrm{Fe}_{2} \mathrm{~W}(\mathrm{CO})_{10}\left(\mu_{3}-\mathrm{S}\right)_{2}\right](\mathbf{1})$ and $\left[\mathrm{CpW}(\mathrm{CO})_{3}\right.$ $\mathrm{C} \equiv \mathrm{CPh}$ ] (2) were prepared by established procedures $[24,25]$.

\subsection{Reaction of $\left[\mathrm{Fe}_{2} \mathrm{WS}_{2}(\mathrm{CO})_{10}\right]$ with $\left[\mathrm{CpW}(\mathrm{CO})_{3}-\mathrm{C} \equiv \mathrm{CPh}\right]$}

To a solution of $\left[\mathrm{Fe}_{2} \mathrm{WS}_{2}(\mathrm{CO})_{10}\right](15 \mathrm{mg}, 0.0234$ $\mathrm{mmol})$ in dry toluene $(30 \mathrm{ml})$ was added $\left[\mathrm{CpW}(\mathrm{CO})_{3^{-}}\right.$ $\mathrm{C} \equiv \mathrm{CPh}$ ] (25 mg, $0.0504 \mathrm{mmol})$. The reaction mixture was heated at $80^{\circ} \mathrm{C}$ for 20 min under an atmosphere of nitrogen. The solution was cooled to room temperature, and the solvent was removed in vacuo. The residue was dissolved in a minimum amount of $\mathrm{CH}_{2} \mathrm{Cl}_{2}$ and was chromatographed using silica gel TLC plates. Use of $60 / 40 \mathrm{v} / \mathrm{v}$ hexane-dichloromethane mixture afforded a dark brown band 3 (20 mg, 61\%).

3: IR [v(CO) $\mathrm{cm}^{-1}$ ]: 2075 (vs), 2043 (vs), 2032 (m), 2011 (s), 1983 (w), 1963 (m), 1943 (m), 1934 (s). UV [dichloromethane, $\lambda_{\max }, \mathrm{nm}\left(\varepsilon, \mathrm{M}^{-1} \mathrm{~cm}^{-1}\right)$ ]: 556 (2596), 418 (10340), 283 (41149), 232 (57021). ${ }^{1} \mathrm{H}-\mathrm{NMR}$ $(\delta, \mathrm{ppm}): 5.71\left(\mathrm{~s}, \mathrm{C}_{5} \mathrm{H}_{5}\right), 7.52-7.54\left(\mathrm{~m}, \mathrm{C}_{6} \mathrm{H}_{5}\right)$. M.p. $238-240^{\circ} \mathrm{C}$ (decomposition). Anal. Calc. (found) for $\mathrm{C}_{38} \mathrm{Fe}_{2} \mathrm{H}_{20} \mathrm{O}_{12} \mathrm{~S}_{2} \mathrm{~W}_{3}$ : C, 32.70 (32.50); H, 1.44 (1.50)\%.

\subsection{Structural characterisation of $\mathbf{3}$}

Crystal data $\left(\mathrm{C}_{19} \mathrm{H}_{10} \mathrm{FeO}_{6} \mathrm{SW}_{1.50}, \quad M=697.96\right.$, orthorhombic, Pnab, $a=18.921(3), b=11.338(1), c=$ 18.939(3) $\AA, V=4062.9(10) \AA^{3}, Z=8, D_{\text {calc }}=2.282 \mathrm{mg}$ $\mathrm{m}^{-3}, \quad$ wavelength $=0.70930 \AA \AA \quad \mu\left(\mathrm{Mo}-\mathrm{K}_{\alpha}\right)=9.324$ $\mathrm{mm}^{-1}$. Rectangular single crystals of deep brown color were grown by slow evaporation of the compound from a mixture of dichloromethane and hexane. Crystal of dimensions of $0.35 \times 0.35 \times 0.3 \mathrm{~mm}^{3}$ was used for data collection and X-ray data were collected on a PC controlled Enraf-Nonius CAD-4 single crystal X-ray diffractometer (MACH-3). The structure was solved by direct methods using sHELXs-86 and refined by full-matrix least-squares on $F^{2}$ using SHELXL-97 [26]. The initial solution yielded the coordinates of all $\mathrm{W}, \mathrm{Fe}, \mathrm{S}$ and few carbon atoms. Successive difference Fourier maps revealed the rest of the structure. The X-ray analysis of the complex shows that the two halves of the molecule are related by symmetry. Least squares refinement of scale, positional and anisotropic thermal parameters of all the atoms was carried out except the $\mathrm{Cp}$ ring which showed orientational disorder and $\mathrm{Cp}$ ring atoms have been refined isotropically [27]. Cp ring is disordered and there are two different positions for the atom $\mathrm{C} 19$. Atoms $\mathrm{C} 19$ and $\mathrm{C} 19^{\prime}$ were refined with 0.5 occupancy. The central four atoms in both the rings superpose, as their movements get smeared out in the thermal parameters. Out of 4249 reflections collected, in the $\theta$ range of 2.09-24.92, $(0 \leq h \leq 22,0 \leq k \leq 13,0 \leq$ $l \leq 22)$ in $\omega / 2 \theta$ scan mode using graphite monochromatised $\mathrm{Mo}-\mathrm{K}_{\alpha}$ radiation, 3577 were independent. The data with 237 refined parameters, converged to $R_{1}=$ $0.0488, R w=0.1286$, from 3577 unique reflections ([I> $2 \sigma(I)])$.

\section{Supplementary material}

Crystallographic data for the structural analysis have been deposited with the Cambridge Crystallographic Data Centre, CCDC no. 155321. Copies of this information may be obtained from The Director, CCDC, 12 Union Road, Cambridge CB2 1EZ, UK (fax: + 441233-336-033; e-mail: deposit@ccdc.cam.ac.uk or www: http://www.ccdc.cam.ac.uk).

\section{Acknowledgements}

Crystallographic analysis was carried out at the $\mathrm{Na}-$ tional Single Crystal X-ray Diffraction Facility, IIT Bombay.

\section{References}

[1] M.S. Khan, A.K. Kakker, S.L. Ingham, P.R. Raithby, J. Lewis, B. Spencer, F. Wittmann, R.H. Friend, J. Organomet. Chem. 472 (1994) 247.

[2] C.W. Faulkner, S.L. Ingham, M.S. Khan, J. Lewis, N.J. Long, P.R. Raithby, J. Organomet. Chem. 482 (1994) 139.

[3] A. Abe, N. Kinura, S. Tabata, Macromolecules 24 (1991) 6238.

[4] H.B. Fyfe, M. Mlekuz, D. Zergarian, N.J. Taylor, T.B. Marder, Chem. Commun. (1991) 188.

[5] G. Gia, R. Puddephatt, J.J. Vittal, N.C. Payne, Organometallics 12 (1993) 263.

[6] G. Gia, N.C. Payne, J.J. Vittal, R.J. Puddephatt, Organometallics 12 (1993) 4771.

[7] S.R. Marder, J.E. Sohn, G.D. Stucky, ACS Symp. Ser. 455 (1991) 605 and references therein.

[8] P.N. Prasad, D.J. Williams, Nonlinear Optical Effects in Molecules and Polymers, Wiley, New York, 1991.

[9] T. Kaharu, H. Matsabara, S. Takahashi, J. Mater. Sci. 32 (1991) 732.

[10] S. Takahashi, Y. Takai, H. Morimoto, K. Sonogashira, Chem. Commun. (1984) 3.

[11] P. Blenkiron, G.D. Enright, A.J. Carty, Chem. Commun. (1997) 483.

[12] Y. Chi, A.J. Carty, P. Blenkiron, E. Delgado, G.D. Enright, W. Wang, S.-M. Peng, G.-H. Lee, Organometallics 15 (1996) 5269.

[13] A.J. Carty, G. Hogarth, G.D. Enright, G. Frapper, Chem. Commun. (1997) 1883.

[14] C.-H. Wu, Y. Chi, S.-M. Peng, G.-H. Lee, Organometallics 10 (1991) 1676.

[15] G.-K. Huang, Y. Chi, S.-M. Peng, G.-H. Lee, J. Organomet. Chem. 389 (1990) C7.

[16] P. Mathur, M.O. Ahmed, A.K. Dash, M.G. Walawalkar, V.G. Puranik, J. Chem. Soc. Dalton Trans. (2000) 2916.

[17] P. Mathur, M.O. Ahmed, A.K. Dash, M.G. Walawalkar, J. Chem. Soc. Dalton Trans. (1999) 1795. 
[18] P. Mathur, M.O. Ahmed, A.K. Dash, J.H. Kaldis, Organometallics 19 (2000) 941.

[19] L.W. Arndt, M.Y. Darensbourg, J.P. Fackler Jr, R.J. Lusk, D.O. Marler, K.A. Youngdahl, J. Am. Chem. Soc. 107 (1985) 7218.

[20] L.W. Arndt, T. Delord, M.Y. Darensbourg, J. Am. Chem. Soc. 106 (1984) 456.

[21] W.-Y. Yeh, C.-L. Ho, M.Y. Chiang, I.-T. Chen, Organometallics 16 (1997) 2698

[22] D.T. Sawyer, A. Sobkowiak Jr, L.J. Roberts, Electrochemistry for Chemists, Wiley, New York, 1995.
[23] S. Chakraborty, M.G. Walawalkar, G.K. Lahiri, J. Chem. Soc. Dalton Trans. (2000) 2875.

[24] P. Mathur, S. Mukhopadhyay, M.O. Ahmed, G.K. Lahiri, S. Chakraborty, M.G. Walawalkar, Organometallics 19 (2000) 5787.

[25] M.I. Bruce, M.G. Humphery, J.G. Matisons, S.K. Roy, G.A. Swincer, Aust. J. Chem 37 (1984) 1955.

[26] G.M. Sheldrick, SHELXL-97, Program for crystal structure solution and refinement, University of Göttingen, Göttingen, Germany, 1997.

[27] T.C.A. North, C.D. Philips, S.F. Mathews, Acta Crystallogr. Sect. A 24 (1968) 351. 